\title{
Генноінженерна біотехнологія
}

УДІК $517.113+123.5$

С. А. Мартинов, I. Г. Бух, Г. 10. Мipю́та,

Т. С. Даниленко, Т. П. Перерва, С. С. Малюта

\section{ВИВЧЕННЯ ФУНКЦІОНАЛЬНОГ РОЛІ ЛЇНІЙНИХ ПЛАЗМІД МІТОХОНДРІЙ КУКУРУДЗИ HA IHTAKTHUX POCJUHAX}

В роботі вивчали здатність мітохондріальних плазмід кукурудзи виконувати в ядрі регуляторну функцію, подібну до той, яку вони здійснюють у мітохондріях. Дая цього до зародку зернівки кукурудзи вводили рекомбінанткі плазміди, які містили S1- та S2послідовності мітохомдріальної ДНК кукурудзи, для того, чоб, виходячи з властивостей рослин нащадків, з'ясувати можливість. включення до метаболізму рослинної клітини лімійних плазмід мітохондрій. Амаліз отримаких на проростках 'сім'ян та на дорослих рослинах кукурудзи даних свідчить про можсливий вплив на життездатність рослиноӧ клітини обробки рослин кукурудзи рекомбінамтними плаэмідами, які містили $S 1-$ та S2-послідовності мітохомдріальної ДНК.

Вступ. Явище цитоплазматичної чоловічої стерильності (ЦЧС) у вищих рослин відомо з 1920 року і до нині інтенсивно вивчається $[1,2]$. Як відомо, в курурудзи виявлено три типи ЦЧС-ЦЧС Т, ЦЧС С i ЦЧС $S$, які спочатку були ідентифіковані за ix відношенням до ядерних генів - відновлювачів фертильності. У ЦЧС ліній S-типу ознаку чоловічої стерильності пов'язують з присутністю у препаратах мітохондріальної ДНК лінійних плазмідоподібних структур, які були названі згодом S1 та S2 [3]. Складність ядерно-цитоплазматичних відносин, що визначають контроль стерильності - фертильності у кукурудзи 3 ЦЧС-цитоплазмою (особливо у випадку S-типу), привела до появи концепціӥ епісомального елемента фертильності, котрий за умов фіксації у цитоплазмі (цитоплазматичні ревертанти) або у ядрі (ядерні ревертанти) обумовлюе виникнення фертильного фенотипу [4]. Щодо цитоплазматичних ревертантів така концепція уявляється досить слушною, тому що останніми роками вона отримала експериментальне підтвердження. Зараз добре відомо, що відновлення фертильності у цитоплазматичних ревертантів ЦЧС-рослин S-типу пов'язане 3 вбудовуванням S1 та S2-послідовностей до мітохондріальної ДНK $[5,6]$. При цьому в мітохондріях спостерігається зникнення вільних форм $\mathrm{S} 1$ та S2 і вбудовування ï до мітохондріальної ДНК здійснюеться у чітко визначених локусах, які прилягають до генів цитохром-с-оксидази та АТФази $[7,8]$. Не дивлячись на те, що механізм цитоплазматичної реверсії не є до кінця зрозумілим, загальна картина виглядає досить чіткою і дозволяє розглядати S1-та.S2-плазміди як регуляторні елементи мітохондріальних генів.

Щодо механізмів здійснення ядерного контролю виявлення стерильності у рослин з ЦЧС-цитоплазмою також є велика кількість робіт. Проте вони, як правнло, мають чисто генетичний характер, i не дозволяють судити про те, наскільки функції генів-відновлювачів пов'язані з функцією S1- та S2-плазмідоподібних структур. 3 одного 60 -

(С. А. МАРТИНОВ, Һ. Г. БУХ, Г. К. МІРЮТА, Т. С. ДАНИЛЕНК,, Т. П. ПЕРЕРВА,

C. С. МАЛЮТА, 1992 
ку, є дані про те, що у відновленні фертильності у ЦЦС-рослин може приймати участь транспозабельний елемент, здатний на додаток до стандартного гена-відновлювача $R F 3$ займати місце на другій хромосомі [9]. 3 іншого боку, Кембел із співавт. [21] показали, що у ядерних ДНК ядерних ревертантів, ЦЧС-стерильних рослин і цитоплазматичних ревертантів $€$ копії S1-послідовності і відсутні копії S2. Крім того, ядро не містить також S1- та S2-копій у вигляді автономних структур. Таким ңином, питання про слушність концепції ролі S1- та S2-плазмідоподібних елементів фертильності на рівні ядра залишається відкритим, оскільки функція S1-копіі, вбудованої до ядерної ДНК, незрозуміла, гакож є незрозумілим, чи здатні S1- та S2-плазміди здійснювати у ядрі регуляторну функцію, подібну до тої, яку вони виконують у мітохондріях. У зв'язку з досягненнями у галузі генетичної інженерії рослин вирішення такого питання здобуло нові можливості. Яку роль відіграє присутність мітохондріальних плазмід у клітинному ядрі, можна з'ясувати шляхом прямого введення до клітини цих ДНК у складі штучних рекомбінантних плазмід. Відомо, шу у тих випадках, коли рекомбінантну плазміду вдаеться впровадити до рослинної клітини, вона виявляється у ядрі $[10,11]$. Серед заходів, розроблених для введення екзогенної ДНК до-рослинної клітини, певні переваги має використання пилкової системи. У перівнянні з системами, які засновані на отриманні протопластів, цей заdсіб простіший i дозволяє провадити роботу з представникаби однодольних на рівні дорослих рослин. Ефективність генетичної трансформації 3 використанням пилкової системи показана для різних видів рослин і генетичних маркерів $[14,15]$. Таким чином, є підстави вважати, що обробка кукурудзяних приймочок сумішшю пилка та. плазмідної ДНК забезпечує входження останньої до клітинного ядра зародку майбутнього зер-на. Порівняння рослин, отриманих в результаті такої обробки, з контрсльними дозволяє судити про наявність або відсутність фізіологічного ефекту подібної дії.

Метою цієі роботи було з'ясування можливості впливу на метаболізм рослинної клітини лінійних плазмід мітохондрій у складі рекомбінантних структур.

Матеріали і методи. У роботі використані фертильна лінія кукурудзи ВIP 44 та її ЦЧС-аналог ВІР 44 ЧС, отримані на Краснодарській дослідній станції. Препарати ядерної ДНК кукурудзи виділяли за методикою [16]; препарати мітохондріальної ДНК - за методом Хемсона та ін. [17]; лінійні структури плазмідоподібних ДНК мітохондрій кукурудзи отримувати, як наведено у [18]. Рекомбінатні плазміди конструювали згідно з методами, наведеними у посібнику [19]. Плазміда $p B R 322$ використана нами як вектор. На іі грунті отримано рекомбінантні плазміди, які містили фрагменти S1- та S2-структур мітохондріальної ДНК кукурудзи. Плазміда, яку назвали $p Z M S 8$, містить фрагмент SI-послідовності від унікального сайту SalG1 та включає область гомології біля 5392 п. о. Друга плазміда, pZMH65, містить фрагмент S2-послідовності від унікального сайту. HindIII до кінця плазміди з областю гомології біля 3600 п. о. У випадку першої плазміди вставку вбудовували за SalG1, а у випадку другої - до сайту HindIII плазміди $p B R 322$. Структуровою особливістю обох гібридних плазмід $€$ неможливість вирізування вставок через поєднання ї 3 векторною молекулою за тупими кінцями.

Рослини обробляли плазмідною ДНК через 1-5 год після запилення кукурудзи впорскуванням розчину ДНК (50 мкr/мл) за ступеня очищення препарату $60-70 \%$ до зав'язі з розрахунку $1,5-2,0$ мл на один качан. За контроль слугували рослини, оброблені такимо ж мином $0,1 \mathrm{M}$ розчином SSC. Зібранй пилок рослин аналізували з метою виявлення морфологічних ознак фертильності і стерильності. При цьому пилок, наповнений крохмальовими зернами, умовно вважали фертильним, а порожній пилок з цілісною оболонкою-стерильним. Мік- 
роскопіюванню піддавали препарати нативного пилку, а також пилок, який було пофарбовано карміном. Отримані результати аналізували як на рівні кількості переглянутих під мікроскопом пилкових гранул, так i на рівні обстежених рослин.

Схожість та динаміку росту сім'ян досліджували, висіваючи ї на $0,75 \%$-е голодне агарізоване середовище у чашках Петрі. Враховували схожість на 3-ю добу. Про динаміку росту сім'ян судили з розміру стеблини на $3,5,7-y$ добу, а також за розміром кореня, який визначали на 3-ю та 7-у добу. Масу отриманих проростків встановлювали на 7-у добу.

Статистичну обробку експериментальних даних робили за [20].

Результати і обговорення. Першу обробку рослин плазмідними ДНК провадили за умов польового досліду у 1985 р. Наступного року насіння рослин кожного варіанту було посіяно на дослідній ділянці, а насіння отриманого врожаю висівали у теплиці у 1986 та 1987 pp. Фізіологічні наслідки обробки рослин плазмідними ДНК спочатку аналізували на рівні пилку за ознакою кількісного співвідношення стерильних i фертильних гранул та за кількістю рослин з стерильним -пилком. Дані цих досліджень наведено у табл. 1. Як можна бачити з наведених даних, оброблені плазмідами варіанти рослин характеризуються достовірним зниженням кількості стерильних зернин 3 відповідним зменшенням кількості рослин (статистично недостовірним), у складі яких виявлялися стерильні пилкові гранули. Слід відзначити, що, хоча зниження кількості рослин із стерильним пилком і виглядає статистично недостовірним через малу вибірку обстежених рослин, проте й у цьому випадку спостерігається та ж тенденція, що і з стерильними гранулами, а саме: найбільше зниження частки стерильних екземплярів відзначається в результаті обробки препаратом ДНК рекомбінантної плазміди $p Z M H 65$, яка містила $\mathrm{S} 2$-послідовність мітохондріальної ДНК кукурдзи. Цей результат став подальшою (вже експериментальною) підставою для вивчення схожості та динаміки росту насіння у.кожному варіанті (табл. 2). Виявлена різниця між контрольними та двома дсслідними варіантами достовірна 3 надійністю $0,9-$

Т а 6 ли и я 1

відносна кількість стерильних пилинок та стерильних рослин у різних варіантах docsidy

\begin{tabular}{|c|c|c|c|c|c|c|}
\hline \multirow{3}{*}{ Варіант досліду } & \multicolumn{3}{|c|}{ Пилннки (III покоління) } & \multicolumn{3}{|c|}{ Рослини (II покоління) } \\
\hline & \multirow[b]{2}{*}{$\begin{array}{c}\text { Загалом } \\
\text { переглянуто }\end{array}$} & \multicolumn{2}{|c|}{ Стерильні зернини } & \multirow[b]{2}{*}{$\begin{array}{c}\text { Загалом } \\
\text { обстежено } \\
.\end{array}$} & \multicolumn{2}{|c|}{3 стерильним пнлком } \\
\hline & & $\begin{array}{l}\text { Кіль: } \\
\text { кість }\end{array}$ & $\%$ & & $\begin{array}{l}\text { Кіль- } \\
\text { кість }\end{array}$ & $\%$ \\
\hline \multirow{2}{*}{$\begin{array}{l}\text { Контроль } \\
\text { Обробка плазмідами: } \\
\text { pZMS8 (S1) } \\
\text { pZMH65 (S2) }\end{array}$} & 80000 & 50 & $0,62 \pm 0,87$ & 35 & 10 & $28,5 \pm 8,55$ \\
\hline & $\begin{array}{l}47000 \\
300001\end{array}$ & $\begin{array}{l}25 \\
10\end{array}$ & $\begin{array}{l}0,05 \pm 0,011 \\
0,03 \pm 0,010\end{array}$ & $\begin{array}{l}33 \\
83\end{array}$ & $\begin{array}{l}2 \\
4\end{array}$ & $\begin{array}{l}6,06 \div 4,24 \\
4,68 \pm 2,40\end{array}$ \\
\hline
\end{tabular}

Т а блиц н 2

Динаміка росту сін'ян, отриманих у дослідни та контрояьних варіантах експеринентів

\begin{tabular}{|c|c|c|c|c|c|c|c|}
\hline Варіант досліду & $\begin{array}{l}\text { Кількість } \\
\text { сім'яH, } \\
\text { які про- } \\
\text { росли }\end{array}$ & $\begin{array}{l}\text { Ko- } \\
\text { pi } \\
\text { MMs }\end{array}$ & $\begin{array}{l}\text { Порівняно } \\
\text { з контро- } \\
\text { лем, \% }\end{array}$ & $\begin{array}{l}\text { Cтеб- } \\
\text { лина, } \\
\text { мM }\end{array}$ & $\begin{array}{c}\text { Порівняно } \\
\text { з контро- } \\
\text { лем, \% }\end{array}$ & $\begin{array}{c}\text { Maca } \\
\text { пророст- } \\
\text { ку, мг }\end{array}$ & $\begin{array}{l}\text { Відносно } \\
\text { контролю, } \\
\%\end{array}$ \\
\hline \multirow{2}{*}{$\begin{array}{l}\text { Контроль } \\
\text { Обробка плазмідами: } \\
\text { pZMS8 (S1) } \\
\text { pZMH65 (S2) }\end{array}$} & 29 & 34 & 100 & 13 & 100 & 345 & 100 \\
\hline & $\begin{array}{l}26 \\
30\end{array}$ & $\begin{array}{l}21,45 \\
43\end{array}$ & $\begin{array}{r}63,018 \\
126,47\end{array}$ & $\begin{array}{l}6,7 \\
20\end{array}$ & $\begin{array}{l}51,54 \\
153,7\end{array}$ & $\begin{array}{l}231: \\
467\end{array}$ & $\begin{array}{r}66,95 \\
136,36\end{array}$ \\
\hline
\end{tabular}


0,99, проте, як можна побачити з даних таблиці, у варіангі обробки рослин плазмідою, яка містила S1, вона зсунута у бік зменшення кількісних ознак, а при обробиі рослин плазмідою, що містила S2,- у бік іх збільшення. Причини цієї відзнаки пояснити важко, особливо якщо врахувати збіг даних обох варіантів за пилком у другому та третьому поколіннях (врожаї 1986-1987рр.). У той же час слід пам'ятати, що коли використаним плазмідам вдається досягнути ядра, то у випадку плазміди pZMS8 воно одержить збільшений набір S1-послідовностей, а у випадку плазміди $p Z M H 65$ - сполучення S1- та $\mathrm{S} 2$-послідовностей, які звичайно є присутніми у мітохондріальній ДНК кукурудзи, шо, мабуть, $є$ найбільш фізіологінним для рослинної клітини цього виду.

Подальше порівняння ознак в оброблених плазмідами та контрольних варіантах робили вже на рівні дорослих рослин. Насіння дослідних варіантів врожаю 1987 (поле) та 1988 рр. (тецлиця) було посіяно та самозапилено у польовому досліді. Рослини одержаного врожаю порівнювали з контрольними за розміром та масою самих рослин, кількістю, масою та довжиною качанів, а також за масою 1000 зернин. За всіма наведеними параметрами потомство рослин, оброблених плазмідою з S1, відповідало контрольним рослинам, тобто виявлене у дослідах на проростках відставання за величиною кореня, стеблини та маси (3-денні прсростки) в дорослих рослин вже не було помітним. У потомсті рослин, оброблених плазмідою $3 \mathrm{S2}$ (V та VI покоління), внявлені статистично достовірні (за надійного рівня 0,95) відміни від. контрольних за масою рослнн та середньою масою усіх качанів на одній рослині. Ці дані зведено до табл. 3.

Т а блиня 3

Порівнлльна харакмеристика потомства рослин, оброблених плазмідою, яка містить $\$ 2$, та контрольних рослин

\begin{tabular}{|c|c|c|c|c|}
\hline Варіант досліду & Маса рослнн, Г & $\begin{array}{c}\text { Порівняно } \\
\text { контролем, } \\
\%\end{array}$ & $\begin{array}{l}\text { Cередня мася } \\
\text { усіх качанів на } \\
\text { однін рослині, г }\end{array}$ & $\begin{array}{c}\text { Порівняно } \\
\text { контролек, } \\
\%\end{array}$ \\
\hline \multirow{3}{*}{$\begin{array}{l}\text { Контроль } \\
\text { Обробка плазмідою } \\
\text { pZM } 265: \\
\text { урожай } 1987 \text { p., } \\
\text { V покоління } \\
\text { урожай } 1988 \text { p., } \\
\text { VI покоління }\end{array}$} & $3386,7 \pm 62,40$ & 100 & $233,11 \pm 37,32$ & 100 \\
\hline & $1040,29 \pm 67,13$ & 292,318 & $3184,78 \pm 23,52$ & 165,14 \\
\hline & $1141,86 \pm 172,14$ & 292,82 & $406,60 \pm 62,00$ & 174,51 \\
\hline
\end{tabular}

Таким чином, ми виявили, що в рослин, оброблених рекомбінантною плазмідою, яка містить S1-послідовність, спочатку спостерігається нестабільне підвищення життєздатності, про шо судили з складу пилку нащадків другого покоління, 3 наступним пригніченням характеристик росту (проростки рослин третього покоління) та поступове вирівнювання іх до рівня контрольних рослин (дорослі рослини $V$ та VI поколінь). У нащадків рослин, оброблених рекомбінантною плазмідою, яка містила S2-послідовність, спостерігаються стійкі статистично достовірні відзнаки від контрольних варіантів у бік посилення характеристик росту та збільшення частки фертильних пилкових гранул. Цей ефект цілком можна порівнювати 3 ефектом, який спостерігається при вбудовуванні мітохондріальних плазмід до мітохондріальної ДНК у процесі цитоплазматичної реверсії до фертильності, - підвищенням загального енергетнчного рівня та життєздатності рослини. Слід відзначити, що як і у випадку наведеної в літературі цитоплазматичної реверсії, в' наших експериментах головні зміни спостерігалися на рослинах, оброблених плазмідою, яка містила S2-послідовності мітохондріальної ДНК кукурудзи. Порівняння отриманих нами експериментальних результатів 3 даними Кембела 3 співавт. [21], які встановили 
наявність у ядерній ДНК кукурудзи тількн копій структури S1 та від. сутність S2-копій, дозволяє висунути припущення про те, що на рівні мітохондріальної та на рівні ядерної ДНК життездатність рослинної клітини підвищується за умови вбудовування до них обох типів мітохондріальних плазмід.

\section{СПИСОК ЛIТЕРАТУРИ}

1. Laughman J. R., Gabay-Laughman $S$. Cytoplasmic male sterility in maize//Ann. Rev. Gerret.-1983.- 17.-P. 27-48.

2. Tudzynski $P$. Pogmann $P$., Neuhaus $H$. Extrakaryotic inheritance: mitochondrial genetics//Progr. Bot.-1986.- 48.- P. 249-253.

3. Unique DNA associated with mithochondria in the " $S$ " type cytoplasms of male sterile maize / D. R. Pring, C. S. Levings, W. W. G. Hu, D. H. Timothy // Proc. Nat. Acad. Sci. USA.- 1977.-74, N 7.- P. 2409-2908.

4. Hanson M. R., Conde M. F. Functioning and variation of cytoplasmic genomes: lessons from cytoplasmic-nuclear interactions affecting male fertility in plants//Int. Rev. Cytol-1985-94-D. 213-267.

5. Thompson R. D., Kemble R. J., Flavell R. B. Variations in mitochondrial DNA organization between normal and male-sterile cytoplasms of maize//Nucl. Acids. Res.1980--8, N 9.- P. 1999-2008.

6. Schardl $C . L_{.}$. Pring $D . R$., Lansdale D. M. Mitochondrial DNA rearrangements associated with fertile revertants of S-type male-sterile maize//Cell-1985.-43, N 2.P. $361-368$.

7. Characterization of cytoplasmic male sterility in Petunia hybrida and Zea mays. Localization and activity of cytochromic oxidase / R. J. Bho, I. C. J. M. Suurs, S. J. de Hoop et al.//Euphytica.- 1986-35, N 3.- P. 905-918.

8. The mitochondrial genome of fertile maize (Zea mays L.) contains two copies of the gene enconding the $\left(\alpha\right.$-subunit of the $F_{i}-$ ATPase/P. G. Isaac, A. Brennicke, S. M. Dunbar, C. J. Leaver//Curr. Genet.-1985.-10, N 2-P. 32!-328.

9. Cytoplasmic reversion of cms-S in maize association with a transpositional event/ C. S. Levings, B. D. Kim, D. R. Pring et al.//Science.-1980-209, N 4.- P. 102I1023.

10. Chimeric genes as dominant selectable markers in plant cells/L. Herrera-Estrella, M. de Block, E. Massens et al.//EMBO J.-1983.-2, N 6.- P. 987-995.

11. Direct gene transfer to plants/J. Paszkowski, R. D. Shillito, $M$. Saul et al.//Ibid.1984.-3, N. 12.- P. $2717-2722$.

12. Uptake, integration, expression and genetic transmission of a selectable chimaeric gene by plant protoplasts/R. Hain, P. Stabel, A. P. Czernilofsky et al.//Mol, and Gen. Genet.-1985.-199, N 1.- P. 161-168.

13. Direct gene transfer to cell of a graminaceans monocot/J. Potricus, M. W. Saul, J. Petruska et al.//Ibid.-P. 183-188.

14. Ohta $Y$. High-efficiency genetic transformation of maize by a mixture of pollen and exogenous DNA//Proc. Nat. Acad. Sci. USA.-1986.-83, N 5.-P. 715-719.

15. Hess $D$. The pollen system of gene transfer//Genetic manipulation in plant breeding.Berlin; New York: Walter de Gruyter and Co, 1986.- P. 803-811.

16. Watson J. C., Thompson W. F. Purification and restriction endonuclease analysis of plant nuclear DNA//Meth. Enzymol.-1986.-118.-P. 57-63.

17. The isolation of mitochondria and mitochondrial DNA/M. R. Hanson, M. L. Boeshore, P. E. McClean et al.//Ibid.-P. 437-443.

18. Levings $C . S$., Pring $D . R$. Restriction endontclease analysis of mitochondrial DNA from normal and texas cytoplasmic male-sterile maze// Science.-1976-193, N 4228.-P. $158-161$.

19. Маниатис T., Фрич Э., Сэмбрук Дж. Молекулярное клоннрование.-М.: Мир. $1984 .-477 \mathrm{c}$.

20. Плохинский $H$. A. Биометрические методы в генетических исследоваяиях // Актуал. вопр. соврем. генетики.- $М .:$ : ГУ, 1966.-602 с.

21. Kemble R. J., Thompson R. D. S1 and $\mathrm{S} 2$, the linear mitochondrial DNAs present in a male sterile line of maize, possess terminally ottached proteins//Nucl. Acids Res.1982.- 10, N 24.-P. 8181-8190.

Ін-т молекуляр. бірлогї̈ і генетики АН України, Кнїв

Одержано 14.10 .91 